\title{
Basal Cell Carcinoma: Experience in a Teaching Hospital, Calabar-South Nigeria
}

\author{
Maurice Asuquo $^{1}$, Otei Otei ${ }^{1}$, Victor Nwagbara1, Godwin Ebughe ${ }^{2}$, Joshua Omotoso ${ }^{2}$ \\ ${ }^{1}$ Department of Surgery, University of Calabar Teaching Hospital, Calabar, Nigeria; ${ }^{2}$ Department of Pathology, University of \\ Calabar Teaching Hospital, Calabar, Nigeria. \\ Email: \{mauefas2, onte333, aikay_en, gobeng01, ayomemee\}@yahoo.com
}

Received December $1^{\text {st }}$, 2010; revised December $28^{\text {th }}, 2010$; accepted January $4^{\text {th }}, 2011$.

\begin{abstract}
Background: Basal cell carcinoma (BCC) is the commonest malignancy among Caucasians in Europe, North America, and Australia. This study attempted to identify the prevalence, risk factors, and outcome of management of this problem in our region. Methods: All the patients with histologic diagnosis of BCC presenting to the University of Calabar Teaching Hospital, Calabar during the study period January 2000 to December 2009 were evaluated. Results: One hundred and fifty two patients (136 blacks, 16 albinos) were afflicted with skin malignancy, squamous cell carcinoma and BCC totaled 70 [SCC-62, BCC-8], and malignant melanoma (MM)-16. Of the 8 patients, (3 males and 5 females, mean age 43 years, range 21 - 65 years) observed with BCC lesions, 2 (25\%) were darkly pigmented and 6 (75\%) were albinos. Most of the albinos who presented 3 decades before the darkly pigmented ranged in age from 21 - 60 years (mean 35.7 years). The lesions afflicted the head and neck region, 9 (82\%), while 2 (18\%) were observed on the upper limb. All the patients had excision with satisfactory results during the period of follow up that ranged from 6 months to 3 years (mean 13 months). Conclusion: BCC is an uncommon lesion in our region. Albinism and solar radiation were identified risk factors. Most of the albinos presented 3 decades earlier than the darkly pigmented. Early institution of preventive measures, early diagnosis, and treatment would result in better outcome.
\end{abstract}

Keywords: Basal Cell Carcinoma, Albinos, Darkly Pigmented

\section{Introduction}

Basal cell carcinoma (BCC) is undisputedly the commonest dermatological malignancy among Caucasians in Europe, North America, and Australia, occurring typically in areas of chronic sun exposure, usually slow growing and rarely metastasize $[1,2]$. In the United States, approximately $80 \%$ of invasive skin cancers are BCC while $20 \%$ are squamous cell carcinoma (SCC) [3]. Ultraviolet radiation (UVR) is the most important risk factor in the development of BCC [4]. In Africa, Albinism and environmental exposure to sunlight are established risk factors for the development of BCC [5]. There are numerous variations in clinical presentation of BCC such as nodular BCC, ulcerating BCC, pigmented BCC, sclerosing BCC, superficial BCC, and fibroepithelioma of Pinkus [6]. Despite its very high prevalence, BCC is generally a low-grade neoplasm, it can be locally invasive and destructive rarely metastasizes and amenable to excision management [7]. We present this study in an attempt to highlight the prevalence, risk factors, and outcome of treatment of this lesion in our setting.

\section{Patients and Methods}

All the patients with histologic diagnosis of BCC presenting to the University of Calabar Teaching Hospital during the study period January 2000 to December 2009 were evaluated as part of a wider study of skin malignancies. The variables analyzed included, age, gender, number of lesions, clinical presentation, site of lesion, human immunodeficiency virus (HIV) serology, treatment, outcome, follow up, and skin pigmentation. This was compared with total number of skin malignancies and total number of SCC seen during the same period.

\section{Results}

In total, 152 patients were afflicted with skin malignancy during the study period (136 blacks, 16 albinos). BCC accounted for $5 \%$ of all skin malignancy, $9 \%$ of all epidermal malignancy, and $11 \%$ of all non-melanoma skin cancer. Sixteen albinos (SCC-9, BCC-6, and MM-1) were seen and accounted for $10.5 \%$ of patients with skin 
malignancy, Table 1. Actinic keratoses were observed in all the albinos afflicted with SCC, BCC, and MM. Patients with other malignancies did not show any with actinic keratoses.

The 8 patients with BCC (3 men and 5 women) whose ages ranged from 21 through 65 (mean 43 years) accounted for $5 \%$ of skin malignancy seen in our institution during the study period. All the patients were seronegative for human immunodeficiency virus (HIV) and there was no other evidence of immunosuppression.
Table 2 shows the clinicopathological features and outcomes of BCC. Two (25\%) darkly pigmented (one man and one woman) both aged 65 years were observed, while 6 (75\%) were albinos ( 2 men and 4 women). The ages of the albinos ranged from 21 - 60 years (mean 35.7 years). Actinic keratoses afflicted all the albinos indicating chronic exposure to sunlight and were found only on the exposed parts of the body (Head/neck and upper limb) and contrast sharply with the darkly pigmented that showed no keratoses.

Table 1. Skin malignancies in Calabar (2000 - 2009).

\begin{tabular}{|c|c|c|c|}
\hline Type of malignancy & Total number of patients (\%) & Total number of lesions & Remarks \\
\hline Squamous cell carcinoma & $62(41.0)$ & 62 & $\begin{array}{c}53 \text { blacks, } \\
9 \text { albinos }\end{array}$ \\
\hline Kaposi sarcoma & $50(33.0)$ & 73 & All blacks \\
\hline Malignant melanoma & $16(11.0)$ & 16 & $\begin{array}{c}15 \text { blacks, } \\
1 \text { albino }\end{array}$ \\
\hline Dermatofibrosarcoma protuberans & $11(7.0)$ & 11 & All black \\
\hline Basal cell carcinoma & $8(5)$ & $11^{*}$ & $\begin{array}{l}2 \text { blacks, } \\
6 \text { albinos }\end{array}$ \\
\hline Malignant adnexal tumour & $5(3.0)$ & 5 & All blacks \\
\hline Total & $152(100)$ & & $\begin{array}{c}136 \text { blacks, } \\
16 \text { albinos }\end{array}$ \\
\hline
\end{tabular}

*The 11 BCC tumours found in 8 patients, the albinos accounted for $82 \%$ ( 9 out of 11) of the lesions.

Table 2. Clinicopathological features and outcomes of BCC.

\begin{tabular}{|c|c|c|c|c|c|c|c|c|}
\hline S/No. & $\begin{array}{c}\text { Age } \\
\text { (years) }\end{array}$ & Gender & $\begin{array}{l}\text { No. of } \\
\text { Lesions }\end{array}$ & Clinical Presentation & Site & Treatment & $\begin{array}{c}\text { Outcome } \\
\text { (Follow-up) }\end{array}$ & Remarks \\
\hline 1 & 58 & Male & 1 & $\begin{array}{l}\text { Mass (5 months) mobile, } \\
30 \times 15 \mathrm{~mm}\end{array}$ & Head (forehead) & Excision & $\begin{array}{l}\text { Healed } \\
\text { (2 years) }\end{array}$ & Albino \\
\hline 2 & 60 & Female & 1 & $\begin{array}{l}\text { Mass left arm ( } 6 \text { months), } \\
80 \times 65 \text { mm, mobile. }\end{array}$ & $\begin{array}{l}\text { Upper limb (lateral } \\
\text { side of left arm) }\end{array}$ & Excision & $\begin{array}{l}\text { Healed } \\
\text { (3 years) }\end{array}$ & Albino \\
\hline 3 & 30 & Male & 1 & $\begin{array}{l}\text { Right sided facial mass } \\
\text { ( } 3 \text { months), } 40 \times 25 \mathrm{~mm} \text {, } \\
\text { mobile. }\end{array}$ & Head (Right cheek) & Excision & $\begin{array}{c}\text { Healed } \\
\text { (9 months) }\end{array}$ & Albino \\
\hline 4 & 21 & Female & 3 & $\begin{array}{l}\text { Mobile left sided masses } \\
(7 \text { months }) . \text { Shoulder }(15 \\
\times 20 \mathrm{~mm} . \text { Neck }(30 \times 15 \\
\text { mm }) \text { Arm }(25 \times 15 \mathrm{~mm})\end{array}$ & $\begin{array}{l}\text { Neck (1) (left supra } \\
\text { clavicular) } \\
\text { Upper limb (2), lateral } \\
\text { arm and forearm }\end{array}$ & Excision & $\begin{array}{l}\text { Healed } \\
\text { (1 year) }\end{array}$ & Albino \\
\hline 5 & 25 & Female & 2 & $\begin{array}{l}2 \text { masses }(3 \text { months }) \\
\text { (Forehead) mobile, } 25 \times \\
20 \mathrm{~mm} \text { and } 15 \times 10 \mathrm{~mm} .\end{array}$ & Head (forehead) & Excision & $\begin{array}{l}\text { Healed } \\
\text { (1 year) }\end{array}$ & Albino \\
\hline 6 & 22 & Female & 1 & $\begin{array}{l}\text { Chronic ulcer (5 months) } \\
20 \times 35 \mathrm{~mm}\end{array}$ & Head (Pre auricular) & Excision & $\begin{array}{c}\text { Healed } \\
\text { (18 months) }\end{array}$ & Albino \\
\hline 7 & 65 & Female & 1 & $\begin{array}{l}\text { Chronic ulcer } 8 \text { months) } \\
30 \times 35 \text { mm, mobile. }\end{array}$ & Head (Right paranasal) & Excision flap & $\begin{array}{c}\text { Healed } \\
\text { (6 months) }\end{array}$ & $\begin{array}{c}\text { Darkly } \\
\text { pigmented }\end{array}$ \\
\hline 8 & 65 & Male & 1 & $\begin{array}{l}\text { Huge ulcerated mass ( } 2 \\
\text { years) } 220 \times 200 \mathrm{smm} \text {. }\end{array}$ & Head (Occi put) & $\begin{array}{l}\text { Excision flap } \\
\text { skin graft }\end{array}$ & $\begin{array}{c}\text { Healed } \\
\text { (6 months) }\end{array}$ & $\begin{array}{c}\text { Darkly } \\
\text { pigmented }\end{array}$ \\
\hline Total & & & 11 & & & & & $\begin{array}{l}6 \text { albinos } \\
2 \text { darkly } \\
\text { pigmented }\end{array}$ \\
\hline
\end{tabular}

*Albinos accounted for $82 \%$ (9 out of 11) of the BCC lesions. 
Eleven BCC lesions were observed in total on the 8 patients with 2 patients that presented with multiple lesions. The albinos accounted for $82 \%$ (9 out of 11) of them, Table 2. The clinical forms observed were proliferative and ulcerative lesions, no regional lymphadenopathy, and afflicted the head region in 9 (82\%) patients while the upper limb lesions were found on 2 (18\%) patients, Figure 1. All the patients had excision, the wounds healed with no evidence of recurrence within the period of follow up that ranged between 6 months, and 3 years (mean 13 months).

\section{Discussion}

BCC is an uncommon tumour in our region (5\%) which contrasts sharply with the $80 \%$ incidence in Europe, North America, and Australia [2,8]. The population of Calabar the capital of Cross River State (with a population of 3 million) is 400,000. The low figure recorded in our centre may be due to our small catchments and possibly geographic factors as we are located in the southeastern equatorial rain forest. During the period of study, 9005 patients were seen in the surgical out patient; the patients afflicted with skin malignancy were 152 (1.7\%). Some patients with skin malignancy may have been seen in other facilities in Calabar as tradomedical practitioners enjoy a lot of patronage due to strong sociocultural beliefs. However, our report concurs with reports from other parts of Nigeria; Kano, Northern Nigeria (4\%) [9], Jos, Northern Nigeria 3.9\% [10], and Ilorin, Southwest Nigeria 5.5\% [11]. The occurrence of cutaneous cancers in black patients is an unusual phenomenon, with BCC being particularly uncommon [12]. The major reason for this racial difference in the distribution of skin cancer is the protection from UVR provided by melanin in the darker races [9]. Fair-skinned people account for the overwhelming majority of patients and UV light exposure is the most critical modifiable factor determining early expression and frequency of BCC development [13].

In Africa, several studies reveal a preponderance of SCC $[8,14]$. The BCC/SCC ratio 11\%: 89\% revealed in this study contrast with the $80 \%$ : $20 \%$ typical of the Caucasian population. This may be due to the variation in risk factors with race and environment. The reversal of the BCC/SCC ratio in Caucasians is seen in the setting of immunosuppression in transplant patient [3]. However, none of our patient (BCC, SCC) had evidence of immunosuppression during this study period.

The incidence of albinism in Calabar is not known, however, albinism and environmental exposure to UVR are risk factors for the development of BCC [5]. Seventy five percent of the patients afflicted with BCC lesions were albinos and accounted for $82 \%$ of BCC lesions. All the lesions located on the sun-exposed parts of the body with evidence of actinic keratoses highlighting chronic exposure to sunlight. Ademiluyi and Ijaduola reported that African albinos who develop BCC were a decade younger than black African with this malignancy [15]. The albinos presented 3 decades earlier than the darkly pigmented. This underscores the need for early institution of protective measures against UVR.

BCC is a malignant epithelial neoplasm of the skin rarely observed in patients with intense skin pigmentation [16]. Indeed we observed BCC on 2 (25\%) darkly pigmented patients. In a previous study from this centre, BCC was found only in albinos $[5,8]$. Though these lesions were observed on the head region in both patients, there was however no convincing evidence in support of UVR as a risk factor. BCC development in blacks and indeed in whites in a non-exposed area may represent a different pathogenesis from BCC by UV light exposure [17].

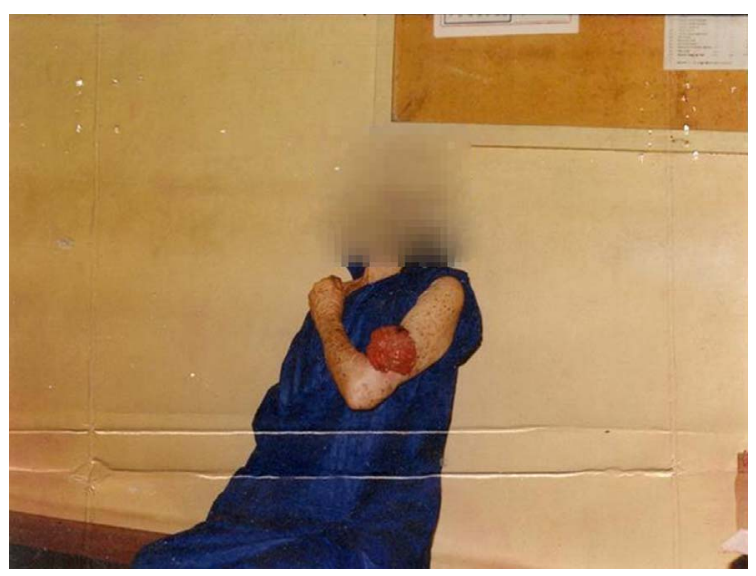

(a)

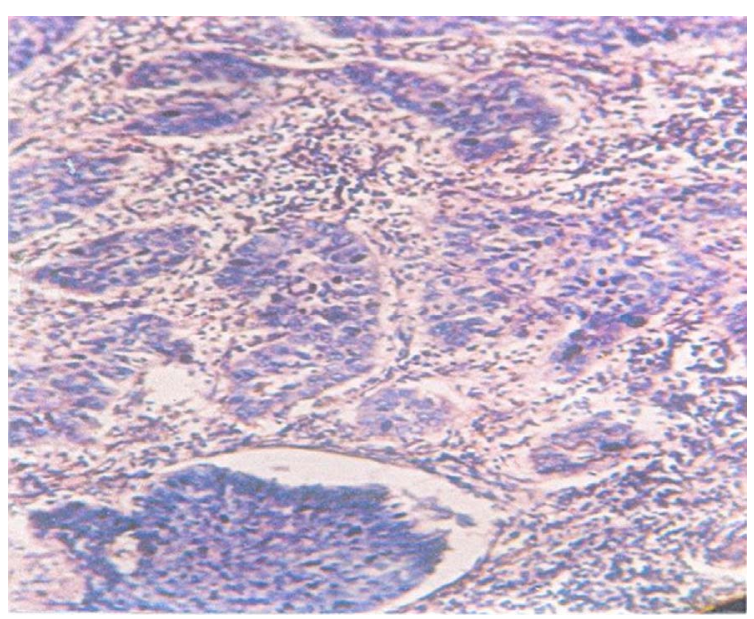

(b)

Figure 1. (a) Clinical photograph, basal cell carcinoma; (b) Basal cell carcinoma, H\&E x 40. 
A characteristic feature of BCC is extremely low risk to metastasize [16]. This was reflected in this study as none of our patients had evidence of lymphatic or systemic metastasis. There are numerous variations in clinical types of BCC [6]. All our patients presented with proliferative or ulcerative varieties. However, BCC lesions can cause significant morbidity if allowed to progress. Cosmetic disfigurement is not uncommon as it affects the head and neck [1].

Treatment modalities include surgical excision, cryosurgery, curettage, electrodessication, radiotherapy, photodynamic therapy, topical cytostatics and immunomodulators [6]. It is generally amenable to excision management [7], indeed all our patients had excision with satisfactory outcome during the period of follow up. Moh's micrographic surgery (MMS) is a preferable modality of treatment because of its high rate of oncologic control as most lesions are found on the head [1].

\section{Conclusions}

BCC is an uncommon lesion in our region seen mostly in albinos. Albinism and solar radiation were identified as risk factors hence the need for early institution of preventive measures in albinos. Early diagnosis and treatment would improve outcome, as generally the lesions are amenable to surgical excision.

\section{REFERENCES}

[1] R. S. Bader, L. Santacroce and A. S. Kenedy, "Basal Cell Carcinoma,” August 31st, 2009. http://emedicine.medscape.com/article/276624-overview

[2] T. L. Diepgen and V. Mahler, "The Epidemiology of Skin Cancer,” British Journal of Dermatology, Vol. 61, Suppl. S61, 2002, pp. 1-6.

[3] N. D. Gross, M. Monroe, "Skin Cancer, Squamous Cell Carcinoma,” January 15th, 2009.

http://emedicine.medscape.com/article/870430-overview. Accessed

[4] M. Situm, M. Buljan, V. Bulat, L. Lugovic Mitel, Z. Bolanca and D. Simic, "The Role of UV Radiation in the Development of Basal Cell Carcinoma," Collegium Antropologicum, Vol. 32, Suppl. 2, 2008, pp. 167-170.

[5] M. E. Asuquo, P. Agweye, G. Ugare and G. Ebughe, "Basal Cell Carcinoma in Five Albino Africans from the South-Eastern Equatorial Rain Forest of Nigeria,” International Journal of Dermatolgy, Vol. 46, No. 7, 2007, pp. 754-756. doi:10.1111/j.1365-4632.2007.03272.x

[6] M. Buljan, V. Bulat, M. Situm, L. L. Mihic and S. Stanic-Duktaj, "Variations in Clinical Presentation of Basal
Cell Carcinoma,” Acta Clinica Croatica, Vol. 47, No. 1, 2008, pp. 25-30.

[7] B. A. Raasch, P. G. Bueffner and C. Garbe, "Basal Cell Carcinoma: Histological Classification and Body Site Distribution,” British Journal of Dermatology, Vol. 155, No. 2, 2006, pp. 401-407. doi:10.1111/j.1365-2133.2006.07234.X

[8] M. E. Asuquo, O. Ngim, G. Ugare, J. Omotoso and G. Ebughe, "Major Dermatological Malignancies Encountered in a Teaching Hospital Surgical Department in South Nigeria," American Journal of Clinical Dermatology, Vol. 9, No. 6, 2008, pp. 383-387. doi:10.2165/0128071-200809060-00004

[9] O. Ochicha, S. T. Edino, A. Z. Mohammed and A. B. Umar, "Dermatological Malignancies in Kano, Northern Nigeria: A Histopathological Review," Annals of African Medicine, Vol. 3, No. 4, 2004, pp. 188-191.

[10] B. M. Mandong, K. S. Orkar, A. Z. Sule and N. L. Dakum, "Malignant Skin Tumours in Jos University Teaching Hospital, Jos, Nigeria,” Nigerian Journal of Surgical Research, Vol. 3, No. 1, 2000, pp. 29-33.

[11] I. A. Adigun, M. O. Buhari and R. O. Ayorinde, "Malignant Skin Tumours in Blacks: Experience in a Teaching Hospital," West African Journal of Medicine, Vol. 25, No. 4, 2006, pp. 276-278.

[12] A. Altman, T. Rosen, J. A. Tschen, T. Hoffman, S. Bruce, D. M. Siegel, M. L. Levy, D. Schaefer and L. H. Goldberg, "Basal Cell Epithelioma in Black Patients," Journal of American Academy Dermatology, Vol. 17, No. 5, 1987, pp. 741-745. doi:10.1016/S0190-9622(87)70256-4

[13] W. Lear, E. Dahlke and C. A. Murray, "Basal Cell Carcinoma: Review of Epidemiology, Pathogenesis and Associated Risk Factors," Journal of Cutaneous Medicine and Surgery, Vol. 11, No. 1, 2007, pp. 19-30.

[14] A. Yakubu and A. Mabogunje, "Skin Cancer in Zaria, Nigeria,” Tropical Doctor, Vol. 25, Suppl. 1, 1995, pp. 63-67.

[15] S. A. Ademiluyi, G. T. Ijaduola, "Occurrence and Recurrence of Basal Cell Carcinoma of the Head and Neck in Negroid and Albino Africans,” Journal of Laryngology and Otology, Vol. 101, No. 12, 1987, pp. 1324-1328. doi:10.1017/S0022215100103780

[16] J. Roewert-Huber, B. Lange-Asschenfeldt, E. Stockfelth, and H. Kert, "Epidemiology and Aetiology of Basal Cell Carcinoma,” British Journal of Dermatol, Vol. 157, Suppl. 2, 2007, pp. 47-51. doi:10.1111/j.1365-2133.2007.08273.x

[17] L. Chorin, J. E. Nirris and M. Gupta, "Basal Cell Carcinoma in Blacks: A Report of 15 Cases," Annals of Plastic Surgery, Vol. 33, No. 1, 1994, pp. 90-95. doi:10.1097/00000637-199407000-00019 